\title{
Lille krig med store konsekvenser
}

\section{Ib Faurby}

\section{Fornemt dansk bidrag til den teoretiske litteratur om international politik med en systematisk analy- se af den russisk-georgiske krig i 2008 og dens konsekvenser for den nye verdensorden}

Hans Mouritzen and Anders Wivel: Explaining Foreign Policy. International Diplomacy and the RussoGeorgian War. Boulder and London: Lynne Reinner Publishers 2012, 223 s.

Den russisk-georgiske krig i august 2008 varede kun fem dage. Den truede Georgiens eksistens som selvstændig stat, og de umiddelbare vestlige reaktioner var højlydte. Nogle kommentatorer mente, at krigen var et vendepunkt $\mathrm{i}$ international politik og begyndelsen på en ny kold krig mellem Rusland og Vesten.

Men der blev hurtigt stille. Hvor Georgien i tiden op til krigen havde stået højt på den internationale dagsorden, forsvandt landet i løbet af få måneder fra mediebilledet, der nu blev domineret af den internationale finanskrise. USA og de øvrige vestlige lande affandt sig tilsyneladende med, at Georgien som en del af Ruslands 'nære udland' lå i dets interessesfære. Der blev ikke længere talt om Georgien og Ukraine som kommende medlemmer af NATO.

I deres nye bog analyserer Hans Mouritzen fra Dansk Institut for Internationale Studier (DIIS) og Anders Wivel fra Københavns Universitets Institut for Statskundskab krigen og spørger:

- Hvorfor besluttede den georgiske ledelse at angribe Sydossetiens 'hovedstad', Tskhinvali, med fare for at fremprovokere et russisk modangreb, som Georgien ikke kunne modstå?

- Hvorfor fortsatte Rusland ikke angrebet, erobrede hele Georgien og afsatte det georgiske styre?

- Hvorfor 'svigtede' USA sin mest loyale ven, Georgien?

- Hvorfor var EU, der ønskede at 
blive en global aktør, så splittet i holdningen til krigen?

- Hvorfor kunne det politisk splittede EU's formand, Frankrigs præsident Nicolas Sarkozy, formidle våbenhvile?

- Hvorfor reagerede staterne i Ruslands 'nære udland' og Kina så forsigtigt på krigen?

Men før forfatterne går i gang med den konkrete analyse af disse spørgsmål, diskuterer de, hvordan man skal forklare staters udenrigspolitik. De skriver nok så beskedent, at deres formål ikke er at konstruere nye teorier, men at anvende teorier fra statskundskabsdisciplinen international politik. Ikke desto mindre er deres bog et af de mest betydningsfulde danske bidrag i mange år til fagets teoriudvikling. Den fortjener indgående anmeldelser i politologiske fagtidsskrifter, ikke mindst i amerikanske. Nærværende omtale vil kun kort referere de centrale elementer, der er nødvendige for at forstå bogens idé.

\section{Systemet eller bureaukratiet}

Mouritzen og Wivel tager udgangspunkt i den skelnen, der er udbredt i faglitteraturen, mellem på den ene side studiet af international politik (det internationale system) og på den anden side studiet af staternes udenrigspolitik. Det vigtigste værk i den første synsvinkel har længe været Kenneth Waltz' Theory of International Politics (1979). Waltz mener, at det overordnede internationale politiske systems karakter (fx multipolaritet, som i den klassiske europæiske magtbalance, eller bipolaritet, som under den kolde krig) er den afgørende determinant for alle staters udenrigspolitik. Unipolariteten efter afslutningen af den kolde krig med USA som den dominerende supermagt er ifølge Waltz ikke en længerevarende tilstand, da andre magter vil forsøge at modbalancere den dominerende magt.

En indflydelsesrig repræsentant for den anden synsvinkel er Graham Allison, der i bogen Essence of Decision: Explaining the Cuban Missile Crisis (1971) præsenterede tre forskellige modeller til forklaring af staters udenrigspolitik. Den første model ser staten som en rationel enhedsaktør (en 'black box'). De to andre (senere integreret i én model) lukker 'den sorte kasse' op og ser på interne organisatoriske og personrelaterede forklaringsfaktorer under betegnelsen 'bureaucratic politics'. Allisons modeller har haft stor pædagogisk betydning, fordi de illustrerer, at de valgte forklaringsmodeller får afgørende indflydelse på såvel, de spørgsmål forskerne stiller, som de svar, de får. Men Mouritzen og Wivel er ikke begejstrede for Allisons relativisme. De ønsker i stedet at integrere de forskellige faktorer i én sammenhængende, konsekvent forklaringsmodel.

De finder hverken Waltz' systemteori eller Alisons 'bureaucratic poli- 


\section{LITTERATUR}

tics'-model tilstrækkelige til at forklare staters konkrete udenrigspolitik. De deler Waltz' (og andres) ønske om teorier, der 'forklarer meget med lidt'. Problemet er blot, at Waltz ikke forklarer ret meget, specielt ikke om små og mellemstore staters udenrigspolitik. Allisons problem er, at han forklarer lidt med alt for meget. Der er så mange og så forskelige forklaringsfaktorer, at der ikke bliver nogen entydig forklaring.

Forklaringer bør være interessante $o g$ så enkle som muligt, skriver Mouritzen og Wivel. Man bør koncentrere sig om 'interessante' forklaringer, der rækker ud over det trivielle, ikke 'fuldstændige' forklaringer. Det betyder, at de ser bort fra mange detaljer, der ikke er afgørende for besvarelsen af de stillede spørgsmål.

Men til de interessante forklaringer mangler et afgørende niveau mellem det internationale system og staternes interne faktorer, nemlig det interstatslige (regionale) niveau. Mouritzen og Wivel er ikke ene om kritikken af Waltz' neorealisme og de forfattere, der som Allison lægger afgørende vægt på interne faktorer til forklaring af staters udenrigspolitik. De såkaldt neoklassiske realister, der har vundet stigende indflydelse i de seneste år, introducerer andre forklaringsfaktorer, men ikke nødvendigvis på en systematisk måde.

Dertil kommer, at de neoklassiske realister har arvet den 'geografiske blindhed', dvs. den manglende forståelse for de geografiske forholds betydning, fra Waltz' neorealisme. Staterne er ikke (med et ofte anvendt billede) bevægelige kugler på det globale billardbord. De er fastlåst $\mathrm{i}$ deres geografiske position, $\mathrm{og}$ hver stat har sine, særlige geografiske omgivelser. Det er i forhold til magtbalancen i deres geografiske omgivelser, de først og fremmest fører udenrigspolitik.

Egentlig er det ikke noget banebrydende synspunkt, at en stats nære omgivelser er af betydning for dens udenrigspolitik. For det har vi jo altid vidst! Sagen er blot, at denne bevidsthed ikke er indgået i de teoretiske forklaringsmodeller. Det forsøgte Hans Mouritzen allerede i 1999 at råde bod på i bogen At forklare international politik.

Han argumenterede for, at den regionale magtbalance (eller 'omgivelsespolaritet') er af større betydning for de små og mellemstore staters udenrigspolitik end den globale polaritet. Det er denne tankegang, der videreudvikles i den foreliggende bog. Om en given stat modbalancerer den dominerende regionale stormagt afhænger af, om det er relevant, muligt og realistisk. Hvis ikke, vil staten i stedet 'bandwagon' med (dvs. støtte) den lokale stormagt.

Når Mouritzen og Wivel skal forklare en stats udenrigspolitik, begynder analysen på det internationale systems niveau. Hvis der her kan gives en tilfredsstillende forklaring på 
statens adfærd, er analysen nået til vejs ende. Hvis der stadig er uforklarede spørgsmål tilbage, fortsættere analysen på det næste niveau, det interstatslige (eller regionale niveau). Kun i de tilfælde, hvor dette heller ikke leder til fyldestgørende resultater, bevæger man sig ned på det indenrigspolitiske niveau for at finde supplerende forklaringer.

Sådan gennemføres analyserne af forfatternes seks hovedspørgsmål til den russisk-georgiske krig og omverdenens reaktioner på den. Det er iflg. Mouritzen og Wivel kun den russiske politik, der kan forklares tilfredsstillende på systemniveau.

USA's og Kinas politik forklares som en kombination af systemniveau og det interstatslige niveau. Kun i fire tilfælde (Georgien, Tyskland, Sverige og Ukraine) er det nødvendigt at inddrage det indenrigspolitiske niveau for at nå til en tilfredsstillende forklaring. De øvrige 34 analyserede staters adfærd forklares tilfredsstillende på det mellemliggende, regionale niveau.

\section{Misforståelse og fejlperception}

Dette er ikke stedet for en nærmere gennemgang af de to forfatteres analyser, men blot nogle illustrationer uden bogens nuancer:

Det var Georgiens præsident Mikhail Saakasjvili, der fremprovokerede krigen med angrebet på Tskhinvali, Sydossetiens 'hovedstad' den 7. august om aftenen. Mouritzen og
Wivels omhyggelige kronologi dementerer påstanden om, at den russiske militære intervention kom først. De tilbageviser den pro-georgiske udlægning af begivenhedsforløbet i fx Ron Asmus' A Little War That Shook the World: Georgia, Russia and the Future of the West (2010).

Mouritzen og Wivel afviser også, at Saakasjvili skulle være faldet i en russisk fælde. Det kan ikke dokumenteres, og Rusland havde advaret Georgien mod et militært angreb. Nærværende anmelder har ikke desto mindre svært ved helt at opgive 'fælde-teorien' som et supplement til forståelse af Saakasjvilis handlinger. Den synes ikke nødvendigvis i strid med Mouritzen og Wivels analyse. Havde Ruslands 'krybende annektering' af Sydossetien (og Abkhasien) og de gensidige provokationer i Sydossetien ikke tvunget Saakasjvili op i den krog, hvor han traf den katastrofale beslutning?

Det georgiske angreb kan ifølge Mouritzen og Wivel hverken forklares ved hjælp af Waltz' systemteori eller ud fra den regionale magtbalance. Den afgørende forklaring finder de i den georgiske ledelses manglende informationer og fejlfortolkning af Ruslands mulige reaktion. Saakasjvili og hans rådgivere undervurderede Ruslands militære styrke. (Rusland kunne jo ikke engang holde orden i sin egen del af Kaukasus). Og de overvurderede effekten af den modernisering, den georgiske hær havde gennemgået 


\section{LITTERATUR}

med amerikansk bistand. Selvom USA havde advaret Saakasjvili mod at provokere Rusland og søge en militær løsning på forholdet til de to løsrivelsesregioner, så havde USA og andre vestlige lande på den anden side også forsøgt at overbevise georgierne om, at det nye Rusland ikke ville forsøge et storstilet angreb. Hverken USA eller Georgien havde forudset en begrænset russisk militær intervention. Og selvom Saakasjvili ikke forventede, at USA militært ville komme Georgien til undsætning, så troede han, at USA diplomatisk ville kunne afskrække en russisk militær intervention.

Medvirkende var ikke kun den georgiske efterretningstjenestes manglende viden, men også USA's manglende konkrete informationer om de russiske militære styrkers deployering på grund af de amerikanske spionsatellitters orientering mod Afghanistan og Pakistan.

\section{Rusland og USA}

Langt enklere er det at forklare Ruslands reaktion. Det kan iflg. forfatterne fuldt tilstrækkeligt gøres på det internationale systems niveau. Set fra Moskva var Georgiens angreb på Tskhianvali en amerikansk inspireret udfordring af Ruslands stormagtsstatus i almindelighed og særlige interesser i Sydkaukasus i særdeleshed. En succesrig reaktion ville være et skridt på vejen mod den multipolære verdensorden, som
Rusland ønskede skulle erstatte USA's unipolære dominans.

Af de reaktionsmuligheder, der stod til Ruslands rådighed, valgte man den begrænsede krig, en hurtig og massiv militær intervention, der ikke førte til erobring af (hele) Georgien eller indsætte et pro-russisk styre i Tbilisi, men 'vandt' Sydossetiens og Abkhasiens definitive løsrivelse. Når Rusland ikke gik videre, er forklaringen, at Rusland på få dage opnåede sit mål: at forsvare sin interessesfære i Sydkaukasus og forhindre georgisk (og ukrainsk) medlemskab af NATO. Med baser i løsrivelsesrepublikkerne ville Rusland være i stand til at gentage succesen, hvis det blev nødvendigt. Samtidig undgik man unødigt at provokere USA til en kraftigere reaktion.

Hvor den tilstrækkelige forklaring på Ruslands adfærd kan findes på systemniveau, kræver forklaringen af USA's forsigtige reaktion inddragelse af supplerende faktorer på det regionale niveau. Den geografiske faktor betød, at Rusland havde maksimal mulighed for magtprojektion i Georgien, mens det fjerne USA ikke havde tilsvarende muligheder.

USA (og dets allierede) ville under ingen omstændigheder risikere en militær konfrontation med Rusland og slet ikke i dette geografiske område. Dertil kom, at USA var militært overbebyrdet på grund af krigene i Irak og Afghanistan kombineret med ustabiliteten i Pakistan og den potentielle konflikt med Iran. USA's 
eneste mulighed var at forsøge at stabilisere de skrøbelige sydkaukasiske stater, først og fremmest Georgien, ved hjælp af 'soft power', primært økonomisk bistand.

\section{Det splittede EU}

EU var splittet i holdningen til krigen. Mouritzen og Wivel kategoriserer EU-landene som henholdsvis 'traditionelle høge' (Storbritannien og Danmark), 'følelsesmæssige høge' (Polen, Estland, Letland og Litauen), 'nykonverterede høge' (Sverige og Finland), 'duer' (Tyskland, Norge, Portugal, Spanien, Irland, Belgien, Slovakiet, Slovenien og Grækenland). Endelig er der 'Ruslands-støtten', Italien. Frankrigs rolle som formidler af våbenhvilen omtales separat.

Man kan diskutere denne kategorisering og især betegnelsen 'følelsesmæssige høge'. Den forekommer ejendommeligt og ude af trit med bogens øvrige analytiske terminologi. Var disse landes reaktioner mere følelsesladede end de øvrige landes? Og havde ikke også disse lande historiske og sarlige geopolitiske grunde til at reagere, som de gjorde?

Analysen af de enkelte EU-landenes reaktioner på krigen sker med udgangspunkt i de tre kriterier for afbalancering (relevans, mulighed og realisme), hvor styrke, geografi og økonomisk afhængighed indgår. Kun i to tilfælde, Tyskland og Sverige, finder forfatterne det nødven- digt at inddrage interne faktorer. For Tysklands vedkommende havde den kollektive erindring om Anden Verdenskrig ført til en ikke-konfrontatorisk udenrigspolitik, hvortil kom taknemmelighed over, at Rusland havde muliggjort Tysklands samling, og endelig elitens holdning, at en svækket stormagt ikke skal trænges op i en krog, men integreres gennem Einbindung.

I det svenske tilfælde er det Carl Bildts magtfulde position i formuleringen af svensk udenrigspolitik og hans erfaringer fra Balkan, der er den supplerende forklaring på det indenrigspolitiske niveau. Men er ikke også Berlusconis personlige holdning og indflydelse en del af forklaringen på, at Italien som det eneste EU-land støtter Rusland?

Men hvordan kunne det lykkes for dette splittede EU at formidle en våbenhvile mellem Rusland $\mathrm{og}$ Georgien? Formandskabslandet Frankrig havde ikke tidligere vist den store interesse for Sydkaukasus. Men USA's tilbageholdenhed i konflikten og uenigheden i NATO om politikken over for Georgien åbnede mulighed for en mere aktiv rolle for EU, der allerede med sin naboskabspolitik var engageret i Sydkaukasus. Der var mindre uenighed i EU om forholdet til Georgien, end der var i NATO om georgisk medlemskab af alliancen.

Det var denne situation, der gjorde det muligt for præsident Sarkozy at mægle. Det var, med Mouritzen 


\section{LITTERATUR}

og Wivels ord, et 'rent held', at det var Frankrig, som altid havde ønsket en selvstændig udenrigspolitisk rolle for EU, der var formandskabsland under krisen.

\section{Det nære udland - og Kina}

Den sidste landegruppe er staterne i Ruslands 'nære udland' - og Kina, der lidt overraskende ikke får sit eget kapitel. Begrundelsen er, at disse landes reaktioner er ensartet forsigtig: alle støttede de en internationalisering af konflikten og præsident Sarkozys våbenhvileaftale. Ingen af dem kritiserede Ruslands adfærd, mens enkelte kritiserede Georgien. Til Ruslands fortrydelse var der imidlertid ingen af disse stater, der anerkendte Sydossetiens og Abkhasiens uafhængighed. Forklaringen på Kinas forsigtige adfærd er dog en ganske anden end forklaringerne på de øvrige landes reaktioner på krigen.

Baseret på Waltz' systemteori skulle man forvente, at alle disse lande ville støtte Rusland for at modbalancere USA's globale indflydelse. Men det gjorde de ikke. Derfor bevæger analysen sig et trin ned ad abstraktionsstigen til det regionale niveau. Her er det for staterne i 'det nære udland' Rusland, der er den regionale stormagt, hvis indflydelse i givet fald skulle balanceres, men det var ikke realistisk på grund af geografi kombineret med det asymmetriske styrkeforhold og økonomisk afhæn- gighed. For Moldova var der desuden problemet med løsrivelsesregionen Transdnjestr, mens striden om Nagorno-Karabakh spillede en rolle både for Aserbajdsjan og for Ruslands allierede, Armenien. For de centralasiatiske tidligere sovjetrepublikker var det ikke muligt at afbalancere Rusland i samarbejde med Kina, der førte en forsigtig politik i konflikten.

Ukraines reaktion på den russiskgeorgiske krig kan imidlertid ikke fuldt tilfredsstillende forklares på det mellemstatslige niveau. De politiske lederes indbyrdes modstridende tilkendegivelser om krigen var et udtryk for landets interne splittelse mellem den vestlige, vestorienterede del og den østlige og sydlige pro-russiske del samt de modsætninger i regeringskoalitionen, der siden førte til nederlaget for den Orange Revolution. Dertil kom uenigheden mellem den kommende præsident Viktor Janukovitj og Krims lokalparlament om halvøens forhold til Rusland.

Selvom Kina som den opstigende supermagt ifølge Waltz burde modbalancere USA, skete det ikke. Kinas holdning til den russisk-georgiske krig forklares som et kompromis mellem global og regional balancering. Entydig støtte til Rusland kunne styrke Ruslands rolle i Centralasien og skabe en uønsket præcedens for løsrivelsesbevægelser.

Mouritzen og Wivels analyse er nøgtern og teoretisk styret uden mo- 
ralsk eller politisk stillingtagen. Deres konklusioner gælder kun i forhold til de spørgsmål, de har sat sig for at besvare. Men der er naturligvis andre interessante spørgsmål om Kaukasus, Rusland og alle de andre stater, der vil kræve andre analyser og føre til andre konklusioner om de pågældende landes politik.

De to forfattere finder ikke som visse andre analytikere, at spillet om kontrollen med olie- og gasrørledningerne i det sydkaukasisk-kaspiske område er afgørende for at forklare den russiske militære intervention. At krigen væesentligt styrkede Ruslands rolle i dette spil var ifølge forfatterne blot en 'sidegevinst'. Men det var ikke nogen uvæsentlig konsekvens af krigen - hverken for Sydkaukasus eller for Europas energisikkerhed.

Selvom Mouritzen og Wivel koncentrerer sig om de seks indledningsvis formulerede spørgsmål, så har bogen ikke desto mindre perspektiver, der rækker langt ud over de konkrete spørgsmål vedrørende den fem dage lange væbnede konflikt. Krigens forløb og de internationale reaktioner afslørede grundlæggende tendenser i det internationale system, der havde været på vej $\mathrm{i}$ længere tid. Den russiske militære indgriben i den georgisk-sydossetiske konflikt var den første russiske udfordring af den amerikanske verdensorden efter afslutningen af den kolde krig.
Det såkaldte 'reset' i det amerikansk-russiske forhold et halvt år senere var i realiteten en amerikansk indrømmelse af det nye status quo i Sydkaukasus. Sammen med finanskrisen, Kinas fortsat øgede stormagtsstatus og andre staters stigende internationale rolle illustrerede krigen, at det amerikanske hegemoni var slut og verden blevet multipolær, skriver Mouritzen og Wivel.

De har med denne bog ydet et af de sjældne danske bidrag til den internationale faglitteratur. Selvom enkelte dele af deres argumentation kan diskuteres, så er bogen forbilledlig klar i såvel teoridiskussionen som i den konkrete analyse. De faktuelle forhold er detaljeret dokumenteret i et omfattende noteapparat. I det hele taget er det imponerende så meget, der kan formidles på så (relativt) få sider.

Forhåbentlig vil bogen bidrage til at genindsætte politik i studiet af international politik i de dele af det politologiske fagmiljø, der de sidste 10-15 år er kørt af sporet i poststrukturalistisk begejstring. Det gælder ikke mindst den såkaldte diskursanalyse, der sjældent er andet end almindeligheder i esoterisk klædedragt og uden mulighed for at bibringe de sagesløse studerende ny indsigt.

Ib Faurby er cand. scient. pol., tidligere chefkonsulent ved Forsvarsakademiet og medlem af Udenrigs' redaktionskomité. 